\title{
Coulisses
}

Revue de théâtre

12 | Printemps 1995

Varia

\section{Bilan partiel du T.U.M.}

\section{Marcel Kodjovi Djondo}

\section{(2) OpenEdition}

Journals

Édition électronique

URL : http://journals.openedition.org/coulisses/3529

DOI : 10.4000/coulisses.3529

ISSN : 2546-9460

\section{Éditeur}

Presses universitaires de Franche-Comté

\section{Édition imprimée}

Date de publication : 1 mai 1995

Pagination : 93

ISSN : 1150-594X

\section{Référence électronique}

Marcel Kodjovi Djondo, «Bilan partiel du T.U.M. », Coulisses [En ligne], 12 | Printemps 1995, mis en ligne le 15 mars 2019, consulté le 31 octobre 2019. URL : http://journals.openedition.org/coulisses/ 3529 ; DOI : 10.4000/coulisses.3529

Ce document a été généré automatiquement le 31 octobre 2019

Coulisses 


\section{Bilan partiel du T.U.M.}

Marcel Kodjovi Djondo 
1 Durant cette année universitaire 1994-95, le Théâtre Universitaire à Montbéliard a montré un visage différent de ce qu'il a été durant l'année précédente: de la production d'une pièce (Chemins de croix de Kangni Alemdjrodo) qui fut un succès, cette année il est passé à des interventions ponctuelles dans les différents lieux de la vie estudiantine de l'Aire Urbaine 2000. Depuis le début de l'année, il y a eu une quinzaine d'interventions dans les Restaurants Universitaires de Montbéliard et Belfort et dans les amphis pendant les cours!

L'objectif de ces interventions est de manifester la présence d'une vie artistique et culturelle sur les sites universitaires, inciter les étudiants à s'y investir et à s'ouvrir aux manifestations culturelles qui se déroulent dans la ville.

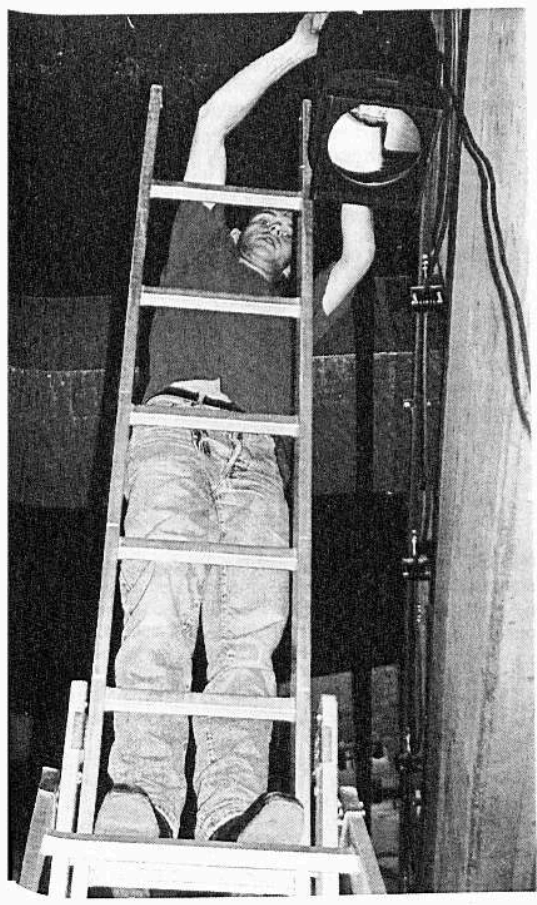
C'est que cette année la présence du Théâtre Universitaire s'est consolidée et il est devenu un élément indissociable du pôle universitaire.

Cependant le nombre d'étudiants fréquentant les ateliers d'expression et d'intervention reste toujours faible. Cet aspect s'inscrit plutôt dans un débat plus large qui est celui de l'intérêt que portent les étudiants à la vie artistique de Montbéliard et de la région. Par exemple, trop peu d'étudiants font partie du public du Centre d'Art et de Plaisanterie qui pourtant donne une âme cultuelle à Montbéliard.

Le prochain pari du TUM sera de renverser la vapeur car le dernier mot n'est pas encore dit ... qu'on se le dise! 